\title{
Kinerja Boiler dengan Sistem Pembakaran Bersama antara Ampas Tebu dengan Sekam Padi dan Cangkang Kelapa Sawit
}

(Boiler Performance Based Co-Firing Bagasse with Rice Husk and Shell Palm Oil)

\author{
SAPTYAJI HARNOWO, YUNAIDI
}

\begin{abstract}
ABSTRAK
Operasional boiler di sebagian besar pabrik gula saat ini banyak yang mengalami kekurangan pasokan bahan bakar ampas tebu karena penurunan kapasitas giling. Kondisi ini menimbulkan masalah terhadap kontinuitas pasokan energi uap dan listrik di pabrik gula, sehingga untuk mengatasi masalah tersebut banyak dilakukan dengan penambahan bahan bakar alternatif dengan model pembakaran bersama (co-firing). Penelitian ini mencoba melakukan kajian model pembakaran bersama ampas tebu dengan sekam padi dan cangkang kelapa sawit berbasis persentase berat bahan bakar. Penelitian dilakukan berdasarkan data operasional boiler di pabrik gula Trangkil saat musim giling tahun 2020. Data yang dikumpulkan meliputi tekanan, kapasitas, dan temperatur uap, serta temperatur air masuk boiler dan temperatur gas buang. Analisis bahan bakar yang dilakukan adalah uji proksimat dan ultimat. Perhitungan dan simulasi pemakaian bahan bakar, kebutuhan volume furnace, efisiensi, dan rugi-rugi boiler dilakukan menggunakan bantuan analisis software Firecad WTPB. Hasil penelitian menunjukkan bahwa co-firing dapat menaikkan efisiensi boiler, menurunkan rugi-rugi boiler, menurunkan pemakaian bahan bakar dan kebutuhan volume furnace, serta menurunkan kecepatan gas buang di sekitar pipa-pipa uap utama. Mitigasi risiko harus dilakukan karena sistem ini dapat meningkatkan temperatur furnace, yang dapat meningkatkan potensi slagging dan fouling sehingga mengganggu kinerja boiler saat musim giling.
\end{abstract}

Kata kunci: Boiler, Co-firing, Ampas Tebu, Sekam Padi, Cangkang Kelapa Sawit.

\section{ABSTRACT}

Boiler operations in most sugar factories are currently experiencing a shortage of bagasse fuel supply due to a decrease in mill capacity. This condition causes problems in the continuity of the steam and the electricity supply in the sugar factory. The research aims to study the co-firing model of bagasse fuel with rice husks and palm oil shells. The research was conducted based on the boiler's operational data at Trangkil sugar factory milling season in 2020. The data collected consisted of the pressure, the capacity, the steam temperature, and the boiler inlet water and flue gas temperature. The fuel analysis carried out is the proximate and ultimate test. The calculations and simulations of fuel consumption, furnace volume requirements, efficiency and losses carried out the computational analysis with Firecad WTPB software. The result shows that the boiler efficiency increases by co-firing and reducing fuel consumption boiler, furnace volume requirements, and gas velocity at boiler banks. The risk mitigation should be investigated during boiler operations because this system can increase the furnace temperature, which can escalate the potential for slagging and fouling as well as pipe erosion so that it interferes with boiler performance during milling season.

Keywords: Boiler, Co-firing, Bagasse, Rice Husk, Palm Oil Shells. 


\section{PENDAHULUAN}

Perkembangan industri gula nasional di pulau Jawa dalam kurun waktu lima tahun terakhir mengalami peningkatan yang sangat cepat dengan adanya penambahan kapasitas olah pabrik gula melalui program PMN (Penyertaan Modal Negara) dalam pengembangan pabrik gula milik BUMN serta pembangunan pabrik gula baru oleh pihak swasta. Dalam kurun waktu 10 tahun terakhir telah dibangun 11 pabrik gula baru baik di pulau Jawa maupun luar pulau Jawa, sehingga menjadikan kapasitas total terpasang pabrik gula baru pada tahun 2020 mencapai 112 ribu TCD (Asosiasi Gula Indonesia, 2020). Disisi lain, produksi gula tebu nasional pada tahun 2020 tercatat sebesar 2,13 juta ton atau bisa dikatakan tidak mengalami peningkatan yang signifikan dalam kurun waktu lima tahun terakhir (Nasution, 2021b). Hal ini disebabkan peningkatan kapasitas produksi pabrik gula tidak diimbangi dengan penambahan luas areal tanaman tebu dan jumlah tebu yang akan digiling, bahkan mengalami penurunan (Nasution, 2021a; Asosiasi Gula Indonesia, 2020).

Kondisi ini menimbulkan permasalahan bagi pabrik gula karena pasokan bahan baku tebu menjadi berkurang akibat peningkatan kapasitas olah pabrik gula tidak diimbangi dengan peningkatan jumlah tebu yang akan digiling, sehingga kapasitas olah maksimum pabrik gula sulit dicapai. Pada saat ini terdapat 62 pabrik gula di Indonesia dengan kapasitas terpasang total 316.95 ribu TCD, dengan 43 pabrik gula dimiliki BUMN dan 19 pabrik gula dimiliki perusahaan swasta. Apabila seluruh pabrik gula ini dapat beroperasi secara optimal dan efisien, maka dapat menghasilkan produk gula sebanyak 3,5 juta ton/tahun. Jika hal ini terealisasi, maka swasembada gula konsumsi akan dapat tercapai (Kemenperin, 2021). Sampai dengan saat ini, meskipun usaha kerjasama penyiapan lahan tebu baru sistem sinergi BUMN antara PT Perkebunan Nusantara dengan Perhutani telah dilakukan, tetapi belum menunjukkan hasil yang memuaskan (Fauzan, 2020).

Hasil kajian efisiensi energi pabrik gula di wilayah PT Perkebunan Nusantara IX Jawa Tengah menunjukkan bahwa akibat berkurangnya pasokan bahan baku tebu yang diolah oleh pabrik mengakibatkan ketersediaan ampas tebu sebagai bahan bakar utama boiler menjadi berkurang sehingga diperlukan bahan bakar tambahan alternatif selama masa giling pabrik. Bahan bakar alternatif biomassa yang ditambahkan antara lain cacahan gergajian kayu, sekam padi, daduk (cane trash), dan biomassa lainnya dengan total biaya suplesi bahan bakar mencapai 12 miliar rupiah (P3GI, 2016).

Salah satu metode untuk mengatasi kekurangan pasokan bahan bakar ampas adalah menggunakan sistem pembakaran bersama ( $\mathrm{co}$ firing). Sistem co-firing adalah pembakaran proses pembakaran dua atau lebih bahan bakar yang berbeda pada boiler untuk membangkitkan daya. Tujuan utama sistem ini adalah menggantikan bahan bakar utama dengan bahan bakar alternatif untuk mendapatkan manfaat tertentu. Co-firing banyak diaplikasikan dengan menggunakan semua jenis boiler yang ada, padahal untuk sebagian jenis boiler awalnya hanya dirancang untuk membakar jenis bahan bakar tertentu atau tidak dirancang untuk sistem co-firing. Deposisi abu merupakan parameter penting pada pembakaran biomassa, karena berkaitan erat dengan biaya operasional boiler. Dua tipe deposisi abu pada pipa dan dinding boiler dikenal dengan istilah slagging dan fouling. Karakteristik slagging dan fouling dari biomassa baik secara individu maupun co-firing dapat mempengaruhi perpindahan panas yang terjadi dan menyebabkan kerugian panas.

Ampas tebu (bagasse) adalah bahan bakar dengan komposisi, konsistensi, dan nilai kalor yang bervariasi. Karakteristik ini tergantung pada iklim, jenis tanah tempat tebu ditanam, varietas tebu, metode panen, dan efisiensi pabrik gula. Secara umum, ampas tebu memiliki nilai kalor antara 1600 s.d. 2400 $\mathrm{kkal} / \mathrm{kg}$. Sebagai bahan bakar utama boiler di pabrik gula, ampas tebu merupakan bahan bakar berserat yang memiliki kadar air antara $48 \%-52 \%$, sedangkan boiler di pabrik gula biasanya di desain dengan kemampuan bahan bakar ampas dengan kadar air $42-57 \%$ dan kadar abu dibawah 2,5\%. Sementara apabila terdapat tambahan bahan bakar biomassa lain seperti limbah kayu memiliki kadar air bervariasi dari $20 \%$ - $60 \%$ dan kadar abu $1 \%$ $15 \%$, sehingga dengan sistem pembakaran cofiring mengakibatkan terjadinya perubahan kadar air dan kadar abu sehingga potensi kinerja boiler akan berubah. Variasi kadar air dan kadar abu dari bahan bakar baik secara individu maupun co-firing akan mengakibatkan 
berubahnya nilai kalor pada aliran gas pembakaran yang mempengaruhi unjuk kerja ruang bakar dan superheater pada boiler (Naude, 2001).

Dalam pemakaian bahan bakar alternatif biomassa perlu dipertimbangkan jumlah kadar abu (\%) serta kandungan unsur di dalamnya yang meliputi unsur yang bersifat basa (alkali) yaitu $\mathrm{Fe}_{2} \mathrm{O}_{3}, \mathrm{CaO}, \mathrm{MgO}, \mathrm{Na}_{2} \mathrm{O}$, dan $\mathrm{K}_{2} \mathrm{O}$ serta unsur yang bersifat asam yaitu $\mathrm{SiO}_{2}, \mathrm{Al}_{2} \mathrm{O}_{3}$, dan $\mathrm{TiO}_{2}$. Kandungan asam dan basa dalam abu memberikan dampak terhadap terjadinya slagging di dapur boiler dan fouling pada peralatan perpindahan panas boiler (piping, superheater, dan air heater). Kandungan abu yang tinggi dalam bahan bakar ampas tebu juga akan menurunkan produksi uap. Semakin tinggi kadar abu pada bahan bakar ampas tebu dengan kadar air yang sama maka jumlah uap yang dihasilkan pada boiler semakin kecil (McIntyre, 2013).

Karakteristik biomassa yang sangat berbeda dari bahan bakar fosil secara umum meliputi perbedaan dalam kadar air, kadar abu, nilai kalor, dan kandungan alkali logam. Kadar abu biomassa biasanya memiliki konsentrasi logam alkali lebih tinggi seperti kalium (K), klorin $(\mathrm{Cl})$, dan silikon $(\mathrm{Si})$, serta memiliki variasi kadar air yang tinggi dan kandungan sulfur yang lebih rendah. Perbedaan fitur bahan bakar biomassa dan kadar abu tidak hanya berpengaruh pada pembakaran, tetapi juga secara signifikan mengubah potensi perilaku kadar abu untuk membentuk deposit pada suhu dibawah ruang bakar dapur boiler dan akan meleleh di atas boiler grate (Rein, 2016).

Penggunaan berbagai jenis biomassa sebagai bahan bakar boiler dapat menimbulkan resiko kontaminasi dan kerusakan yang berbeda pada peralatan pemanas boiler seperti slagging, fouling, korosi, aglomerasi dan sintering. Sekam padi memiliki nilai kalor yang lebih rendah dari ampas tebu tetapi memiliki kadar abu yang lebih tinggi, sehingga membutuhkan penyesuaian dalam pengoperasian boiler saat menggunakan sekam padi sebagai bahan bakar alternatif untuk sistem pembakaran bersama dengan ampas tebu. Berdasarkan analisis komposisi abu ampas tebu dan sekam padi, penerapan sekam padi sebagai bahan bakar cofiring pada boiler di pabrik gula tidak akan menimbulkan potensi kerusakan yang serius seperti slagging, fouling, korosi, sintering, dan aglomerasi, tetapi tingginya persentase kadar abu sekam padi dapat meningkatkan potensi risiko di atas (Yunaidi, Surahmanto, \& Harnowo, 2020).

Pemakaian bahan bakar co-firing antara ampas tebu dengan sekam padi pada fluidized bed boiler combustor menunjukkan bahwa akan terjadi kehilangan efisiensi pembakaran antara $1 \%$ s.d. $1.5 \%$ akibat meningkatnya kadar abu dalam bahan bakar serta menghasilkan rugi panas sebesar $1.5 \%$ akibat kandungan oksigen dalam gas buang (Ninduangdee \& Kuprianov, 2018).

Penelitian tentang pengaruh pemakaian bahan bakar biomassa pada boiler berbasis batubara menunjukkan bahwa pemakaian bahan bakar co-firing antara batubara dengan biomassa dapat menurunkan efisiensi boiler seiring dengan peningkatan persentase biomassa dalam campuran bahan bakar, menurunkan temperatur gas buang, menaikkan kandungan karbon yang tidak terbakar dalam fly ash, dan menaikkan potensi slagging. Di sisi lain potensi emisi gas buang berupa gas NOx akan turun seiring dengan meningkatnya persentase biomassa sehingga lebih aman bagi lingkungan (Wang et al., 2021).

Kinerja boiler sering dinyatakan dalam efisiensi boiler dan rasio penguapan biasanya akan menurun seiring dengan berjalannya waktu. Hal ini disebabkan oleh pembakaran dan kualitas bahan bakar yang buruk, munculnya slagging atau fouling yang menghambat perpindahan panas, kualitas air yang tidak sesuai, dan buruknya perawatan. Efisiensi boiler secara umum dipengaruhi oleh tiga komponen utama, yaitu efisiensi pembakaran, efisiensi termal, dan efisiensi bahan bakar menjadi uap air (fuel to steam). Pengujian efisiensi dilakukan untuk mendeteksi seberapa besar penyimpangan efisiensi boiler dari kondisi terbaik. Pengujian efisiensi dapat dilakukan menggunakan dua metode, yaitu metode langsung atau metode input-output (metode keseimbangan energi), dan metode tidak langsung atau metode kerugian panas (heat loss). Berdasar metode kerugian panas ini, efisiensi boiler berbahan bakar ampas dominan dipengaruhi oleh kerugian panas pada gas buang (flue gas) dan tingkat kebasahan ampas tebu (Patel \& Modi, 2016).

Sebagian besar pengukuran kinerja boiler menggunakan metode kerugian panas mengacu pada standar ASME PTC 4 Fire Steam Generators yang berbasis boiler berbahan bakar batubara. Oleh karena itu, dalam 
pengukuran kinerja boiler yang menggunakan bakar biomassa diperlukan beberapa penyesuaian standar tersebut karena perbedaan parameter bahan bakar yang dipakai.

Berdasarkan kondisi kebutuhan ampas tebu hasil proses pengolahan pabrik tersebut di atas, peneliti melakukan riset terkait kinerja boiler pabrik gula yang menggunakan bahan bakar cofiring antara ampas tebu dengan sekam padi dan cangkang kelapa sawit menggunakan metode kerugian panas (heat loss) sesuai dengan standar ASME PTC 4 Fire Steam Generators.

\section{METODE PENELITIAN}

Pengukuran kinerja boiler dilakukan dengan metode tidak langsung atau metode kerugian panas. Metode penentuan efisiensi ini memperhitungkan semua jenis kehilangan panas yang terjadi di dalam boiler. Efisiensi boiler dihitung dengan menjumlahkan persentase semua kerugian dan mengurangi jumlah kerugian yang dihasilkan ini dari 100 persen. Data yang dibutuhkan dalam penelitian ini meliputi analisis bahan bakar dan data operasional boiler.

Bahan bakar yang digunakan dalam penelitian ini adalah ampas tebu (100\%), campuran ampas tebu $(80 \%)$ dan sekam padi $(20 \%)$, serta campuran ampas tebu (80\%) dan cangkang kelapa sawit (20\%). Analisis bahan bakar yang dilakukan meliputi uji nilai kalor, uji proksimat dan uji ultimat. Adapun data operasional boiler menggunakan data sekunder yang diambil dari data operasional boiler Pabrik Gula Trangkil milik PT Kebon Agung Grup yang berlokasi di Pati Jawa Tengah saat masa giling pada tahun 2020.

Data analisis nilai kalor, proksimat dan ultimat bahan bakar serta data operasional boiler tersebut digunakan untuk mengukur kinerja boiler menggunakan metode tidak langsung atau metode pengukuran efisiensi keseimbangan panas berdasarkan standar ASME PTC 4 Fire Steam Generators (ASME, 2008) yang disesuaikan pemakaiannya berdasarkan bahan bakar biomassa. Efisiensi boiler dapat dinyatakan menggunakan persamaan:

$\eta=\frac{\text { energi bahan bakar-kerugian energi }}{\text { energi bahan bakar }} \times 100 \%$

Atau bisa dinyatakan dalam:

$\eta=\left(100-L_{1}-L_{2}-L_{3}-L_{4}\right) \%$
Keterangan:

$\eta \quad:$ efisiensi boiler

$\mathrm{L}_{1}$ : kerugian panas dalam gas buang

$\mathrm{L}_{2}$ : kerugian panas karena kelembaban $\left(\mathrm{H}_{2} \mathrm{O}\right)$ dan hidrogen $\left(\mathrm{H}_{2}\right)$ dalam bahan bakar

$\mathrm{L}_{3}$ : kerugian karena kelembaban dalam udara

$\mathrm{L}_{4}$ : kerugian kadar abu dalam bahan bakar serta kerugian radiasi dan konveksi pada permukaan

Persamaan-persamaan yang bisa digunakan untuk menentukan kerugian (losses) panas dalam boiler antara lain:

a) Udara teoritis yang dibutuhkan untuk pembakaran:

$=\frac{(11.6 \times \mathrm{C})+\left[34.8 \times\left(\mathrm{H}_{2}-\mathrm{O}_{2} / 8\right)\right]+(4.35 \times \mathrm{S})}{100} \mathrm{~kg} / \mathrm{kg}$

bahan bakar

$\mathrm{C}, \mathrm{H}_{2}, \mathrm{O}_{2}, \mathrm{~S}$ adalah berat atom bahan bakar berdasarkan analisis proksimat dan ultimat.

b) Persentase excess air supplied (\%EA):

$\% \mathrm{EA}=\frac{\text { oksigen dalam flue gas }}{21-\text { oksigen dalam flue gas }} \times 100$

c) Massa gas buang ke cerobong asap (mass flue gas to exhaust chimney):

$$
\begin{gathered}
\mathrm{M}_{\mathrm{fg}}=\mathrm{mCO}_{2}+\mathrm{m} \mathrm{N}_{2}\left(\text { dalam bb) }+\mathrm{m} \mathrm{N}_{2}\right. \text { (dalam AAS) } \\
\left.+\mathrm{m} \mathrm{O}_{2} \text { (dalam } \mathrm{FG}\right)
\end{gathered}
$$

Dengan:

$\mathrm{M}_{\mathrm{fg}} \quad$ : massa gas buang $(\mathrm{kg} / \mathrm{kg}$ bahan bakar)

$\mathrm{m} \mathrm{CO}_{2}$ : massa gas $\mathrm{CO}_{2}$

bb : bahan bakar

$\mathrm{m} \mathrm{N}_{2}$ : massa gas $\mathrm{N}_{2}$

AAS : actual air supplied $(\mathrm{kg} / \mathrm{kg}$ bahan bakar)

FG : flue gas

d) Kerugian panas dalam gas buang $\left(\mathrm{L}_{1}\right)$ :

$$
L_{1}=\frac{m \times C_{p} \times\left(T_{f}-T_{a}\right)}{G C V} \times 100
$$

Dengan:

m : massa gas buang kering $(\mathrm{kg} / \mathrm{kg}$ bahan bakar)

$\mathrm{C}_{\mathrm{p}} \quad$ : kalor spesifik dari gas buang kering $\left(\mathrm{kCal} / \mathrm{kg}{ }^{\circ} \mathrm{C}\right)$

$\mathrm{T}_{\mathrm{f}} \quad$ : temperatur gas buang $\left({ }^{\circ} \mathrm{C}\right)$

$\mathrm{T}_{\mathrm{a}} \quad$ : temperatur ambient $\left({ }^{\circ} \mathrm{C}\right)$

$\mathrm{GCV}$ : nilai kalor biomassa $(\mathrm{kCal} / \mathrm{kg})$ 
e) Kerugian panas karena kelembaban $\left(\mathrm{H}_{2} \mathrm{O}\right)$ dan hidrogen $\left(\mathrm{H}_{2}\right)$ dalam bahan bakar $\left(\mathrm{L}_{2}\right)$ :

$$
\begin{aligned}
L_{2}= & {\left[\frac{M \times\left[584+C_{p} \times\left(T_{f}-T_{a}\right)\right]}{G C V} \times 100\right] } \\
+ & \\
& {\left[\frac{9 x H_{2} \times\left[584+C_{p} x\left(T_{f}-T_{a}\right)\right]}{G C V} \times 100\right] }
\end{aligned}
$$

Dengan:

$$
\begin{aligned}
\mathrm{M}: & \text { massa kelembaban bahan } \\
& \text { bakar dalam setiap kilogram } \\
& \text { bahan bakar } \\
\mathrm{C}_{\mathrm{p}}: \mathrm{:} & \text { kalor spesifik uap kering } \\
& (0.47 \mathrm{kCal} / \mathrm{kg} \text { oC }) \\
\mathrm{H}_{2}: & \text { massa hidrogen dalam setiap } \\
& \text { kilogram bahan bakar }
\end{aligned}
$$

f) Kerugian karena kelembaban dalam udara $\left(\mathrm{L}_{3}\right)$ :

$$
L_{3}=\frac{A A S \times \text { humidity } x C_{p} \times\left(T_{f}-T_{a}\right)}{G C V} \times 100
$$

Dengan:

$$
\begin{aligned}
\mathrm{C}_{\mathrm{p}}: & \text { kalor spesifik uap kering } \\
& \left(0.47 \mathrm{kCal} / \mathrm{kg}{ }^{\circ} \mathrm{C}\right) \\
\text { humidity : } & \text { massa air dalam setiap } \\
& \text { kilogram udara }
\end{aligned}
$$

Karena kondisi temperatur dan kelembaban lingkungan operasional boiler relatif sama, maka dalam analisis efisiensi nilainya dibuat konstan.

g) Kerugian karbon dalam abu yang tidak terbakar (unburnt carbon in ash) dan kerugian radiasi/konveksi pada permukaan
$\left(\mathrm{L}_{4}\right)$

Perhitungan kehilangan panas akibat karbon yang tidak terbakar didasarkan pada kandungan karbon dalam abu boiler, dengan asumsi bahwa abu boiler terdiri dari abu bahan bakar dan karbon yang tidak terbakar. Secara umum perlu dipertimbangkan bahwa bahan bakar padat akan kehilangan panas karena adanya abu terbang (fly ash) dan abu dasar (bottom ash) yang tidak terbakar.

Kerugian radiasi/konveksi permukaan dan kerugian lain yang tidak terhitung umumnya diasumsikan berdasarkan jenis dan ukuran boiler seperti yang diberikan di bawah ini (M.Raut, Kumbhare, \& Thakur, 2014):

- Boiler industri pipa-pipa api (fire tube): $1,5 \%$ s.d. $2,5 \%$

- Boiler industri pipa-pipa air (water tube):

\begin{tabular}{|c|c|c|c|c|c|c|}
\hline Kandungan & $\begin{array}{c}\text { Satuan } \\
\& \\
\text { Simbol }\end{array}$ & $\begin{array}{c}\text { Ampas } \\
\text { tebu }\end{array}$ & $\begin{array}{c}\text { Sekam } \\
\text { padi }\end{array}$ & $\begin{array}{c}\text { Cangkang } \\
\text { sawit }\end{array}$ & $\begin{array}{c}\text { Ampas tebu \& } \\
\text { sekam padi } \\
(80 \% ; 20 \%)\end{array}$ & $\begin{array}{c}\text { Ampas tebu \& } \\
\text { cangkang sawit } \\
(80 \%: 20 \%)\end{array}$ \\
\hline $\mathrm{GCV}$ & $\mathrm{kCal} / \mathrm{kg}$ & 2256 & 3248 & 3461 & 2554 & 2617 \\
\hline \multicolumn{7}{|l|}{ Uji proksimat: } \\
\hline - Moisture & $\%$ adb & 50.00 & 7.85 & 19.45 & 41.57 & 43.89 \\
\hline - Ash & $\% \mathrm{adb}$ & 1.5 & 20.67 & 2.1 & 5.33 & 1.62 \\
\hline - Volatile & $\% \mathrm{adb}$ & 36.9 & 57.96 & 50.9 & 41.11 & 39.7 \\
\hline - Fixed carbon & $\% \mathrm{adb}$ & 12.5 & 13.52 & 27.45 & 12.70 & 15.49 \\
\hline \multicolumn{7}{|l|}{ Uji ultimat: } \\
\hline - Carbon & $\mathrm{C}$ & 23.5 & 35.7 & 40.65 & 27.2 & 28.6 \\
\hline - Hydrogen & $\mathrm{H}$ & 2.8 & 4.48 & 4.69 & 3.3 & 3.4 \\
\hline - Oxygen & $\mathrm{O}$ & 15.6 & 31.30 & 33.16 & 20.3 & 20.9 \\
\hline - Nitrogen & $\mathrm{N}$ & 6.60 & 0.00 & 0.00 & 4.6 & 4.6 \\
\hline - Sulphur & $\mathrm{S}$ & 0.03 & 0.05 & 0.07 & 0.034 & 0.038 \\
\hline
\end{tabular}
$2 \%$ s.d. $3 \%$

- Boiler pembangkit listrik: 0,4\% s.d. $1 \%$

Nilai kerugian karbon dalam abu yang tidak terbakar dan kerugian radiasi atau konveksi pada permukaan serta kerugian-kerugian lain yang tidak dapat dihitung dalam penelitian ini dianggap memiliki nilai yang sama untuk semua jenis bahan bakar yang digunakan.

\section{HASIL DAN PEMBAHASAN}

Hasil karakterisasi bahan bakar yang meliputi analisa nilai kalor, proksimat, dan ultimat, abu hasil pembakaran didapatkan sifat-sifat dasar bahan bakar yang ditunjukkan pada Tabel 1.

TABEL 1. Kandungan dan Komposisi Biomassa Ampas Tebu, Sekam Padi, dan Cangkang Kelapa Sawit 
Berdasarkan tabel 1, nilai kalor terendah dimiliki oleh ampas tebu sebesar $2256 \mathrm{kCal} / \mathrm{kg}$, lebih rendah dibandingkan nilai kalor sekam padi sebesar $3248 \mathrm{kCal} / \mathrm{kg}$ dan nilai kalor cangkang sawit sebesar $3461 \mathrm{kCal} / \mathrm{kg}$. Saat ampas tebu dicampur dengan sekam padi dan ampas tebu dicampur dengan cangkang sawit dengan perbandingan masing-masing sebesar (80\%:20\%), maka nilai kalornya berturut-turut berubah menjadi masing-masing $2554 \mathrm{kCal} / \mathrm{kg}$ dan $2617 \mathrm{kCal} / \mathrm{kg}$. Hal ini menunjukkan bahwa dengan model pembakaran co-firing ampas tebu dan cangkang sawit dengan perbandingan 80\%:20\%, dapat meningkatkan nilai kalor bahan bakar sebesar 13\% - 16\%.

Ampas tebu memiliki kadar kelembaban (moisture) yang paling tinggi $(50 \%)$ apabila dibandingkan dengan sekam padi $(7.85 \%)$ dan cangkang sawit (19.45\%), oleh karena itu pada saat dilakukan pembakaran bersama dengan sekam padi atau cangkang sawit nilai kelembabannya akan menurun sehingga memberikan dampak yang cukup baik untuk kinerja pembakaran di boiler (Orang \& Tran, 2015). Di sisi lain, sekam padi memiliki kadar abu yang paling tinggi (20.67\%) jika dibandingkan dengan kadar abu ampas tebu (1.5\%) dan cangkang sawit (2.1\%), sehingga dapat mempercepat penuhnya ruang bakar pada boiler. Oleh karena itu perlu penyesuaian pengoperasian boiler pada saat menggunakan bahan bakar co-firing ampas tebu dengan sekam padi.

Kandungan sulfur yang relatif kecil pada ampas tebu, sekam padi, dan cangkang sawit maupun campurannya menjadi suatu kelebihan dari biomassa ini karena pada saat digunakan sebagai bahan bakar tidak memberikan dampak buruk terhadap lingkungan dalam pembentukan emisi gas NOx dan SOx (Baxter, 2005).

Hasil pengambilan data sekunder operasional boiler Pabrik Gula Trangkil milik PT Kebon Agung Grup yang berlokasi di Pati Jawa Tengah saat masa giling pada tahun 2020 yang digunakan sebagai acuan perhitungan kinerja boiler dapat dilihat pada Tabel 2 .

Data operasional boiler bersama data analisis bahan bakar ampas tebu, sekam padi, dan cangkang sawit tersebut digunakan untuk menghitung kinerja boiler saat dioperasikan dengan bahan bakar tunggal ampas tebu, atau saat menggunakan sistem pembakaran bersama (co-firing) berdasarkan metode tidak langsung menggunakan bantuan analisis komputer (FireCad WTPB 3.0), yang hasilnya seperti terlihat pada Tabel 3 dan Tabel 4.

TABEL 2. Data Rerata Operasional Boiler Pabrik Gula Trangkil Selama Musim Giling Tahun 2020

\begin{tabular}{lcc}
\hline \multicolumn{1}{c}{ Parameter } & Nilai & Satuan \\
\hline Tekanan uap & 21.6 & Bar \\
Temperatur uap & 327 & ${ }^{\circ} \mathrm{C}$ \\
Aliran uap (steam flow) & 50500 & $\mathrm{Kg} / \mathrm{jam}$ \\
Temperatur air & 115 & ${ }^{\circ} \mathrm{C}$ \\
Temperatur gas buang & 150 & ${ }^{\circ} \mathrm{C}$ \\
Temperatur lingkungan & 33 & ${ }^{\circ} \mathrm{C}$ \\
Oksigen dalam gas & 5 & $\%$ \\
\hline
\end{tabular}

TABel 3. Jumlah Pemakaian Bahan Bakar, Kerugian Panas, Efisiensi, dan Kebutuhan Volume Dapur Boiler

\begin{tabular}{ccccc}
\hline & $\begin{array}{c}\text { Satuan \& } \\
\text { Simbol }\end{array}$ & $\begin{array}{c}\text { Ampas tebu } \\
(\mathbf{1 0 0 \%})\end{array}$ & $\begin{array}{c}\text { Ampas tebu \& } \\
\text { sekam padi } \\
(\mathbf{8 0 \%}: \mathbf{2 0} \%)\end{array}$ & $\begin{array}{c}\text { Ampas tebu \& } \\
\text { cangkang sawit } \\
(\mathbf{8 0 \%}: \mathbf{2 0} \%)\end{array}$ \\
\hline Fuel Consumption & $\mathrm{kg} / \mathrm{jam}$ & 19415.46 & 17160.44 & 15961.11 \\
Air Fuel Ratio $($ AFR) & $\%$ & 4.01 & 4.35 & 4.76 \\
Gas Fuel Ratio $($ GFR) & $\%$ & 4.99 & 5.30 & 5.75 \\
$L_{1}$ & $\%$ & 4.89 & 5.02 & 5.15 \\
$L_{2}$ & $\%$ & 20.94 & 17.91 & 17.17 \\
$L_{3}$ & $\%$ & 0.12 & 0.12 & 0.12 \\
$L_{4}$ & $\%$ & 2.00 & 2 & 2 \\
Boiler Efficiency & $\%$ & 72.05 & 74.95 & 31 \\
Excess Air & $\%$ & 31 & 31 & 81.42 \\
Furnace Volume & $\mathrm{m}^{3}$ & 84.53 & 81.84 & 998.9 \\
Furnace temperature & ${ }^{\circ} \mathrm{C}$ & 968.3 & 997.5 & \\
\hline
\end{tabular}


Tabel 4. Profil Gas Buang yang Melewati Beberapa Peralatan Penukar Panas (Heat Excanger/HE) di Boiler

\begin{tabular}{|c|c|c|c|c|}
\hline \multicolumn{5}{|c|}{ Bahan bakar ampas $(100 \%)$} \\
\hline Heat exchanger & $\begin{array}{c}\text { Pressure drop } \\
\text { (mm kolom air) }\end{array}$ & Temperatur $\left({ }^{\circ} \mathrm{C}\right)$ & Densitas $\left(\mathrm{kg} / \mathrm{m}^{3}\right)$ & Kecepatan $(\mathbf{m} / \mathbf{s})$ \\
\hline Superheater & 34.12 & 793.5 & 0.35 & 14.00 \\
\hline Boiler bank & 317.79 & 331 & 0.58 & 33.10 \\
\hline Air heater & 27.86 & 212 & 0.752 & 8.60 \\
\hline Economizer & 34.57 & 140 & 0.87 & 8.90 \\
\hline \multicolumn{5}{|c|}{ Bahan bakar ampas (80\%):sekam padi (20\%) } \\
\hline Heat exchanger & $\begin{array}{c}\text { Pressure drop } \\
\text { (mm kolom air) }\end{array}$ & Temperatur $\left({ }^{\circ} \mathrm{C}\right)$ & Densitas $\left(\mathrm{kg} / \mathrm{m}^{3}\right)$ & Kecepatan $(\mathbf{m} / \mathbf{s})$ \\
\hline Superheater & 30.65 & 809 & 0.32 & 13.84 \\
\hline Boiler bank & 271.38 & 333 & 0.59 & 30.33 \\
\hline Air heater & 26.85 & 214 & 0.76 & 8.41 \\
\hline Economizer & 32.42 & 141 & 0.88 & 8.58 \\
\hline \multicolumn{5}{|c|}{ Bahan bakar ampas (80\%):cangkang sawit (20\%) } \\
\hline Heat exchanger & $\begin{array}{c}\text { Pressure drop } \\
\text { (mm kolom air) }\end{array}$ & Temperatur $\left({ }^{\circ} \mathrm{C}\right)$ & Densitas $\left(\mathrm{kg} / \mathrm{m}^{3}\right)$ & Kecepatan $(\mathbf{m} / \mathbf{s})$ \\
\hline Superheater & 24.35 & 809 & 0.32 & 12.30 \\
\hline Boiler bank & 225.38 & 335 & 0.60 & 27.40 \\
\hline Air heater & 26.67 & 215 & 0.77 & 8.30 \\
\hline Economizer & 32.30 & 142 & 0.88 & 8.60 \\
\hline
\end{tabular}

Meskipun temperatur gas buang pada dapur boiler yang mengalir ke bagian heat exchanger cenderung naik (Tabel 3 dan Tabel 4), tetapi kenaikannya masih dalam rentang operasional boiler berbasis biomassa dan masih memenuhi standar operasional yang diacu. Selain itu kenaikan temperatur gas buang pada dapur boiler dan komponen heat exchanger masih dibawah titik leleh (melting point) abu bahan bakar tersebut yang berkisar pada temperatur $1350^{\circ} \mathrm{C}$ (De Palma et al., 2019) (Horák et al., 2019) (Fredericci et al., 2014) (Li et al., 2013). Oleh karena itu co-firing ampas tebu dengan sekam padi maupun cangkang kelapa sawit cukup aman diaplikasikan pada boiler.

Kerugian panas terbesar dalam sistem operasional boiler adalah kerugian akibat kelembaban (moisture) yang terdapat dalam bahan bakar $\left(\mathrm{L}_{2}\right)$ diikuti oleh kerugian panas yang terdapat dalam gas buang $\left(\mathrm{L}_{1}\right)$. Kedua jenis kerugian ini memiliki peran utama dalam menurunkan atau menaikkan efisiensi boiler. Semakin rendah kandungan moisture dalam bahan bakar dan semakin rendah temperatur gas buang maka akan meningkatkan efisiensi boiler (Dzurenda \& Banski, 2017). Pembakaran bahan bakar biomassa pada tingkat kelembaban yang sesuai sangat penting dari sudut pandang kinerja boiler (Panchal et al., 2016).

Pemakaian bahan bakar secara co-firing antara ampas tebu dengan sekam padi atau cangkang kelapa sawit dapat menaikkan efisiensi boiler dari $72.05 \%$ menjadi $75.56 \%$, dan menurunkan jumlah konsumsi bahan bakar karena nilai kalor bahan bakar co-firing lebih tinggi dibandingkan nilai kalor ampas tebu. Kebutuhan volume ruang bakar (furnace) boiler juga mengalami penurunan, hal ini disebabkan bahan bakar ampas memiliki densitas rendah dan akan terbakar secara melayang di dalam rangka bakar boiler. Bahan bakar jenis ini sifatnya cenderung menumpuk sehingga membutuhkan volume furnace yang lebih besar. Pemakaian bahan bakar secara co-firing dengan sekam padi dan cangkang kelapa sawit akan meningkatkan densitas campuran dan akan mengurangi volume furnace dari $84.53 \mathrm{~m}^{3}$ menjadi 81.42 $\mathrm{m}^{3}$. Hal ini disebabkan bahan bakar sekam padi dan cangkang sawit akan terbakar di atas rangka bakar boiler.

Tabel 4 menunjukkan bahwa kecepatan aliran gas buang hasil pembakaran co-firing di bagian alat penukar panas (heat exchanger) boiler seperti superheater, boiler bank, air heater dan economizer cenderung menurun berbanding langsung dengan pressure drop dan berbanding terbalik dengan densitas gas. Hal ini berdampak lebih baik yaitu menurunkan kemungkinan terjadinya erosi pipa boiler akibat benturan senyawa kotoran atau larutan padat yang terikut dalam gas buang (Yang et al., 2009).

Selama operasional boiler terlihat adanya 
kecepatan gas buang yang mencapai 27.40 $30.33 \mathrm{~m} / \mathrm{s}$ di pipa-pipa utama penghasil uap di sekitar drum atas boiler (boiler bank), sehingga perlu perhatian khusus terkait pengaturan kecepatan gas buang pada sistem IDF (induced draft fan) untuk mengurangi potensi erosi pipapipa boiler bank.

\section{KESIMPULAN}

Berdasarkan hasil analisis yang ditemukan menunjukkan bahwa pemakaian bahan bakar co-firing antara ampas tebu dengan sekam padi dan cangkang kelapa sawit menunjukkan kecenderungan menurunkan kerugian panas pada boiler, sehingga efisiensi boilernya akan meningkat, oleh karena itu aplikasi bahan bakar co-firing dapat dilakukan di pabrik gula. Substitusi bahan bakar sekam padi dan cangkang kelapa sawit sebesar 20\% tidak akan mengubah desain ruang bakar boiler, karena justru akan menurunkan volume ruang bakar boiler. Pemakaian bahan bakar co-firing dapat meningkatkan temperatur furnace dari $968.3^{\circ} \mathrm{C}$ menjadi $998.9^{\circ} \mathrm{C}$ sehingga perlu diwaspadai potensi terjadinya slagging dan fouling di dalam alat alat penukar panas boiler. Diperlukan perhatian dalam operasional boiler terutama dari aspek erosi pipa boiler apabila terjadi slagging dan fouling dalam furnace karena kecepatan aliran gas buang yang cukup besar.

\section{DAFTAR PUSTAKA}

ASME. (2008). Fired steam generators performance test codes. New York, NY: American Society of Mechanical Engineers.

Asosiasi Gula Indonesia. (2020). National sugar summit 2020. Buletin AGI IKAGI Edisi 5, $1-60$.

Baxter, L. (2005). Biomass-coal cocombustion: Opportunity for affordable renewable energy. Fuel, 84(10), 12951302.

https://doi.org/10.1016/j.fuel.2004.09.02 3

De Palma, K. R., García-Hernando, N., Silva, M. A., Tomaz, E., \& Soria-Verdugo, A. (2019). Pyrolysis and combustion kinetic study and complementary study of ash fusibility behavior of sugarcane bagasse, sugarcane straw, and their pellets - Case study of agro-industrial residues. Energy and Fuels, 33(4), 3227-3238. https://doi.org/10.1021/acs.energyfuels. 8 b04288

Dzurenda, L., \& Banski, A. (2017). Influence of moisture content of combusted wood on the thermal efficiency of a boiler. Archives of Thermodynamics, 38(1), 6374. https://doi.org/10.1515/aoter-20170004

Fauzan, M. R. (2020). Sinergi BUMN \& swasta, Perhutani kembangkan industri non-kayu. Retrieved from https://www.wartaekonomi.co.id/read29 8975/sinergi-bumn-swasta-perhutanikembangkan-industri-non-kayu

Fredericci, C., Ett, G., Lenz e Silva, G. F. B., Neto, J. B. F., Landgraf, F. J. G., Indelicato, R. L., \& Ribeiro, T. R. (2014). An analysis of Brazilian sugarcane bagasse ash behavior under thermal gasification. Chemical and Biological Technologies in Agriculture, 1(1), 1-9. https://doi.org/10.1186/s40538-0140015-z

Horák, J., Kuboňová, L., Dej, M., Laciok, V., Tomšejová, Š., Hopan, F., \& Koloničný, J. (2019). Effects of the type of biomass and ashing temperature on the properties of solid fuel ashes. Polish Journal of Chemical Technology, 21(2), 43-51. https://doi.org/10.2478/pjct-2019-0019

Kemenperin. (2021). Kemenperin jaga ketersediaan bahan baku gula untuk industri mamin. Retrieved from https://www.kemenperin.go.id/artikel/22 284/Kemenperin-Jaga-KetersediaanBahan-Baku-Gula-untuk-IndustriMamin

Li, W., Li, Q., Zhang, Y., \& Meng, A. (2013). Ashing temperature's impact on the characteristics of biomass ash. Applied Mechanics and Materials, 261-262, 217223.

https://doi.org/10.4028/www.scientific.n et/AMM.260-261.217

M.Raut, S., Kumbhare, S. B., \& Thakur, K. C. (2014). Energy performance assessment of boiler at P.S.S.K. Ltd, Basmathnagar, Maharashtra State. International Journal of Emerging Technology and Advanced Engineering, 4(12), 1-12. 
McIntyre, P. (2013). Case studies of biomass co firing. FFF OIB Workshop, John Thompson Boiler and Environmental Solution, (September), 2013.

Nasution, D. D. (2021a). Kementan: Lahan tebu terus berkurang, daya saing menurun. Retrieved from https://republika.co.id/berita/qkal0w370/ kementan-lahan-tebu-terus-berkurangdaya-saing-menurun

Nasution, D. D. (2021b). Produksi gula 2020 capai 2,13 juta ton. Retrieved April 28, 2021, from https://republika.co.id/berita/qmgl6w370 /produksi-gula-2020-capai-213-juta-ton

Naude, D. P. (2001). Combustion of bagasse \& woodwaste in boilers for integration into a cogeneration steam cycle. In Proceedings of the 2001 Conference of the Australian Society of Sugar Cane Technologists held at Mackay, Queensland, Australia (p. pp.384-389 ref.4).

Ninduangdee, P., \& Kuprianov, V. I. (2018). Co-combustion of rice husk pellets and moisturized rice husk in a fluidized-bed combustor using fuel staging at a conventional air supply. Songklanakarin Journal of Science and Technology. https://doi.org/10.14456/sjstpsu.2018.134

Orang, N., \& Tran, H. (2015). Effect of feedstock moisture content on biomass boiler operation. TAPPI Journal, 14(10), 629-636.

P3GI. (2016). Laporan audit pabrik gula PTPN IX tahun 2016. Surakarta.

Panchal, R., Shinde, S., \& Panchal, S. (2016). Effect of Bagasse Moisture on Boiler Performance. International Research Journal of Multidisciplinary Studies, 2(1), 1-8.

Patel, D. T., \& Modi, K. V. (2016). Performance evaluation of industrial boiler by heat loss method ., 2(3), 20812088. Retrieved from http://ijariie.com/AdminUploadPdf/Perf ormance_evaluation_of_industrial_boile r_by_heat_loss_method_ijariie2348.pdf

Rein, P. (2016). Cane Sugar Engineering 2nd edition. Verlag Dr. Albert Bartens KG.
Wang, X., Rahman, Z. U., Lv, Z., Zhu, Y., Ruan, R., Deng, S., ... Tan, H. (2021). Experimental study and design of biomass co-firing in a full-scale coalfired furnace with storage pulverizing system. Agronomy, 11(4), 1-11. https://doi.org/10.3390/AGRONOMY11 040810

Yang, H., Zhang, H., Yang, S., Yue, G., Su, J., \& Fu, Z. (2009). Effect of bed pressure drop on performance of a CFB boiler. Energy and Fuels, 23(6), 2886-2890. https://doi.org/10.1021/ef900025h

Yunaidi, Surahmanto, F., \& Harnowo, S. (2020). The risk analysis of rice husk of co-firing fuel for boilers in sugar mills. Journal of Physics: Conference Series, 1446(1). https://doi.org/10.1088/17426596/1446/1/012041

PENULIS:

Saptyaji Harnowo

Program Studi Teknologi Mesin, Politeknik LPP. Jl. Urip Sumoharjo No.1, Klitren, Gondokusuman, Yogyakarta.

Email: saptyaji.lpp@gmail.com

Yunaidi

Program Studi Teknologi Mesin, Politeknik LPP. Jl. Urip Sumoharjo No.1, Klitren, Gondokusuman, Yogyakarta.

Email: ynd@polteklpp.ac.id 